\title{
Investigation of Swings Caused by Sudden Wind Loads During Operation of an Aerial Ladder
}

Széchenyi István University Department of Applied Mechanics

Faculty of Mechanical Engineering. Informatics and Electrical Engineering, Hungary

F. Hajdu
Assistant lecturer
Széchenyi István University
Department of Mechatronics
and Machine Design
Faculty of Mechanical Engineering,
Informatics and Electrical Engineering
Hungary
R. Kuti
Associate Professor
Széchenyi István University
Department of Mechatronics
and Machine Design
Faculty of Mechanical Engineering,
Informatics and Electrical Engineering
Faculty of Mechanical Engineering
Hungary

In Hungary, as in other countries around the world, intervention firefighting units often use a mechanically operated aerial ladder for highaltitude rescue tasks. The safe operation of the equipment is only possible under strict safety regulations and requires a high level of expertise from the operating staff. During each intervention, extraordinary events such as sudden wind gusts can occur, which can cause extreme overload of the structural members of aerial ladders and have adverse effects on the equipment that can lead to malfunctions and - even worse - to accidents. Therefore it is important to study the consequences of external influences on aerial ladders during operation. The examination was performed on a widely used Magirus M32-L aerial ladder. The reason for choosing this type of aerial ladder is because it has a wide operating range, therefore test results can be a good starting point for other similar equipment as well. In this paper the development of our beam model and the performed finite element simulations are presented. The aim of the research is to develop a model based on geometrical measurement data that is suitable for studying the effects of wind gusts on the ladder structure. With our research, we aim to contribute to the safe operation of aerial ladders and to prevent possible accidents.

Keywords: aerial ladder, beam model, wind gust, finite element simulation

\section{INTRODUCTION}

After reviewing the available literature on the subject, it was found that similar studies had been carried out only to determine the operating parameters of aerial ladders [1$3]$. The results of accident investigations are not public and are not accessible to outside researchers. Therefore, as a first step, the operating parameters of the selected aerial ladder were examined. Then the operating reports where a sudden wind gust would adversely affect the equipment were selected. The wind force scale published by OMSZ (Hungarian Meteorological Service) was taken into account for determining the wind force. In order to obtain practical results, the behavior of the equipment was examined at four different wind loads. Using the data from the manufacturer's catalog and our own geometrical measurements, an operation diagram was created (Figure 1). Based on the geometrical data, a $3 \mathrm{D}$ beam model was created and a finite element simulations were carried out. Phenomena that could lead to serious structural injuries or accidents were identified. The investigation of the behavior of the aerial ladder under wind gusts was also motived that our place of residence, North-West Hungary is the windiest region of our country therefore firefighters carry out high-altitude rescue tasks during varying wind events.

Received: December 2019, Accepted: February 2020

Correspondence to: Péter HORVÁTH, Assistant

lecturer, Széchenyi István University (SZE),

Egyetem tér 1, Győr 9026, Hungary

E-mail: horvpe@sze.hu

doi:10.5937/fme2002351H

(C) Faculty of Mechanical Engineering, Belgrade. All rights reserved
Nowadays, the use of aerial ladders has expanded. The main requirement for these structures is to carry out safe rescue of persons in danger from high altitudes or from hard-to-reach places. Therefore, the equipment was strengthened and at the end of the ladder structure a basket for rescuing people and working at height was installed. The range of application of aerial ladders above $30 \mathrm{~m}$ operating height is greatly limited due to the increased weight, larger space requirements and limited stability due to the small support surface. Therefore ladders with a working height of 30 meter are the most widespread.

In Hungary, Magirus M 32L aerial ladders are the most widely used at fire brigades, therefore this type is examined in detail in this paper. The ladder is equipped with an automatic support system. The ladder itself consists of 4 members, is telescopically extendable and is lifted by hydraulic cylinders. The uppermost ladder is also equipped with a rescue basket and a fire extinguishing system. The ladder structure has a maximum lift of $75^{\circ}$ as it can be seen on the operating diagram (Figure 1).

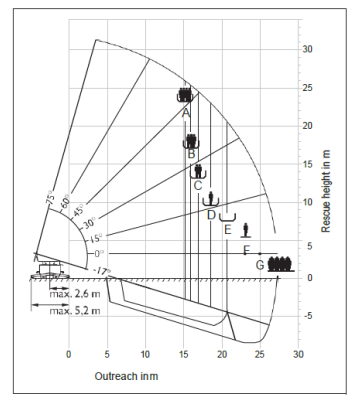

Figure 1. Operation diagram

FME Transactions (2020) 48, 351-356 351 
The members of a ladder structure were accurately measured before developing the model. The equipment is shown in Fig 2.

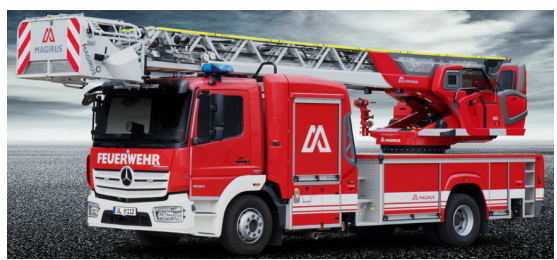

Figure 2. Magirus M 32L Aerial Ladder (from manufacturer's catalog)

\section{BEAM MODEL OF THE LADDER}

As the geometry of an aerial ladder is rather complex, analytic methods cannot be used for calculations [4] therefore finite element method (FEM) has been used. As the ladder is built upon hollow sections, beam element is a suitable element type to create the finite element model of the ladder. There are many commercial FEM softwares available to develop a finite element model, but in case of a ladder with repeated beam segments, and with a special load distribution discussed in chapter 2.2, it is more convenient to write a dedicated code, that can handle easily and parametrically the whole geometry and load cases, therefore Matlab was chosen to develop the finite element model. Figure 3 shows the beam model of the ladder created with Matlab. The shapes and dimensions of the sections are shown in Figure 4 and summarized in Table 1, along with the dimensions of each segment.
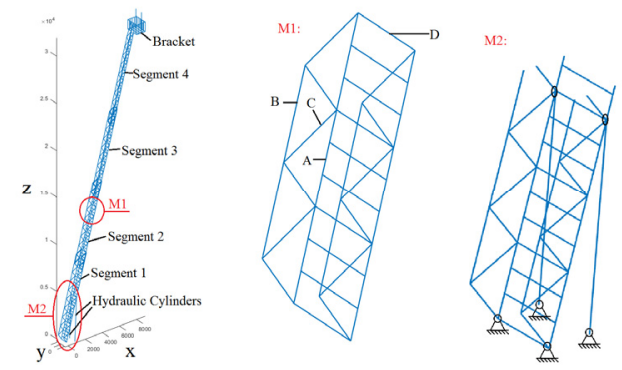

Figure 3. The beam model of the aerial ladder

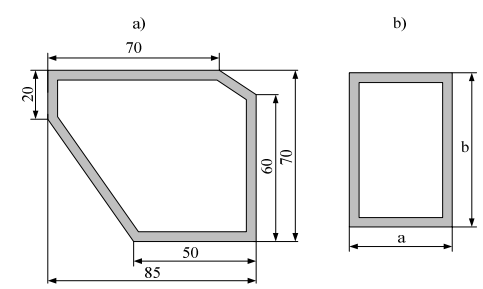

Figure 4. Hollow sections of the ladder a) lower sections (notated with A), b) other sections (notated with B-D). The values of $a$ and $b$ are summarized in Table 1.
The thickness of the hollow sections is $4 \mathrm{~mm}$. The ladder is lifted up by two hydraulic cylinders with a piston rod diameter of $110 \mathrm{~mm}$ and cylinder tube diameter of $150 \mathrm{~mm}$. The two cylinders are connected to the ladder with a pin connection, allowing the angular rotation around $y$ axis. The ladder is supported by four pinned support - as illustrated in Figure 3 - which prevent displacement in all three directions. The bracket of the ladder is built upon hollow sections of $30 \times 30$ $\mathrm{mm}$ with two beam elements in it representing two men with $100 \mathrm{~kg}$ weight. The segments are connected to each other with rigid beam elements, the overlap between the segments is $180 \mathrm{~mm}$. The material of the hollow sections is aluminium with a Young-modulus of $\mathrm{E}=71000 \mathrm{MPa}$, Poisson's ratio of $v=0.33$ and density of $\rho=2770 \mathrm{~kg} / \mathrm{m}^{3}$

\subsection{Finite element discretization}

In case of finite element modelling, the beams of the ladder have to be divided into a finite number of beam elements, as a result of which a discrete system is given, the dynamic behavior of which can be described with (1) ordinary differential equation [5]:

$$
\mathbf{M q}+\mathbf{K q}=\mathbf{f}
$$

where $\mathbf{M}$ is the mass matrix, $\mathbf{K}$ is the stiffness matrix, $\mathbf{f}$ is the nodal force vector and $\mathbf{q}$ is the unknown nodal displacement vector of the finite element model of the ladder. For the analysis two-node three dimensional beam elements were used, which can be loaded with axial and shear forces, bending and torque moments. In case of bending, Euler-Bernoulli theory was adopted [6]. In case of this element type, each node have six degrees-of-freedom - three translations and three rotations - as illustrated in Figure 5.

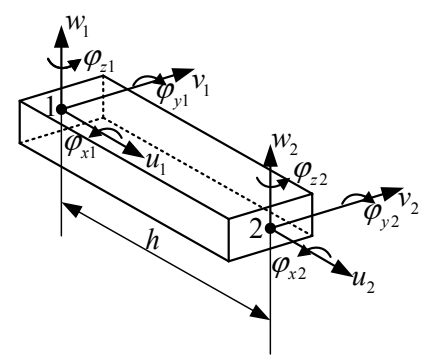

Figure 5. 3D beam element

The construction of the mass and stiffness matrices requires the calculation of the following real constants:

- The cross-section area (A)

- Moment of inertia about $y$ and $z$ axes $\left(\mathrm{I}_{\mathrm{y}}, \mathrm{I}_{\mathrm{z}}\right)$

- Torsional constant (J)

Table 1. Main dimensions of the aerial ladder

\begin{tabular}{|c|c|c|c|c|c|c|c|c|c|}
\hline & \multicolumn{6}{|c|}{ Hollow section dimensions [mm] } & \multicolumn{3}{|c|}{ Segment dimensions [mm] } \\
\hline & \multicolumn{2}{|c|}{ B } & \multicolumn{2}{|c|}{$\mathrm{C}$} & \multicolumn{2}{|c|}{ D } & \multirow{2}{*}{$\begin{array}{l}\text { Segment } \\
\text { length }\end{array}$} & \multirow{2}{*}{$\begin{array}{l}\text { Segment } \\
\text { width }\end{array}$} & \multirow{2}{*}{$\begin{array}{r}\text { Segmen } \\
\text { height }\end{array}$} \\
\hline & $\mathrm{a}$ & $\mathrm{b}$ & $\mathrm{a}$ & $\mathrm{b}$ & $\mathrm{a}$ & $\mathrm{b}$ & & & \\
\hline Segment 1 & 45 & 60 & 25 & 45 & 25 & 50 & 9045 & 765 & 475 \\
\hline Segment 2 & 30 & 50 & 25 & 40 & 25 & 40 & 9008 & 645 & 452 \\
\hline Segment 3 & 30 & 40 & 25 & 35 & 25 & 40 & 9008 & 510 & 403 \\
\hline & & & & & & & 9032 & 385 & 344 \\
\hline
\end{tabular}


These properties can be obtained from the geometry of the cross sections. According to [8] in case of a 3D, two point Euler-Bernoulli beam element with length of $h$, the mass, stiffness matrices in the local coordinate system can be calculated according to (2) and (3), where $G$ is the shear modulus. Knowing the line loads, the nodal force vector can be calculated according to (4).

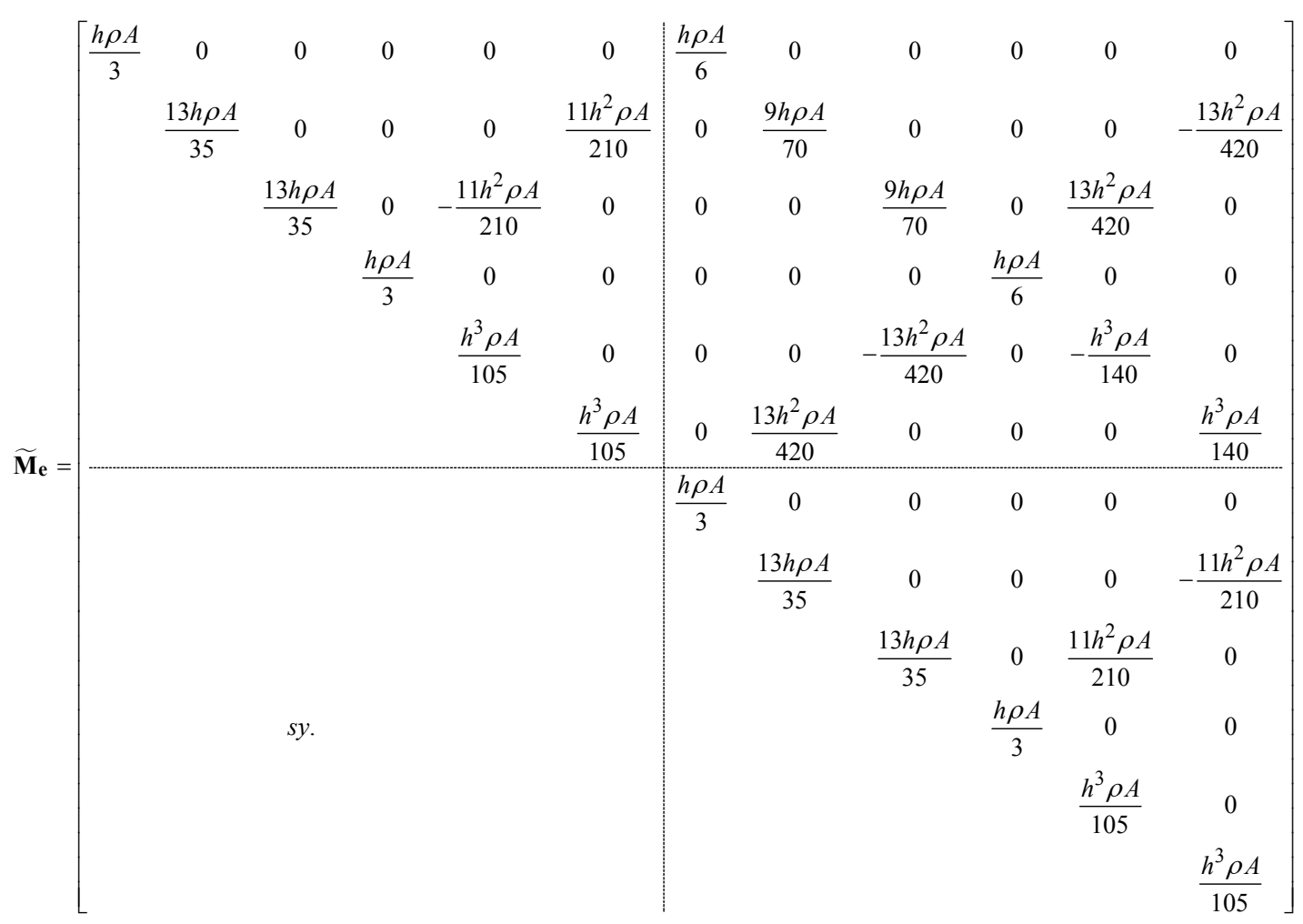

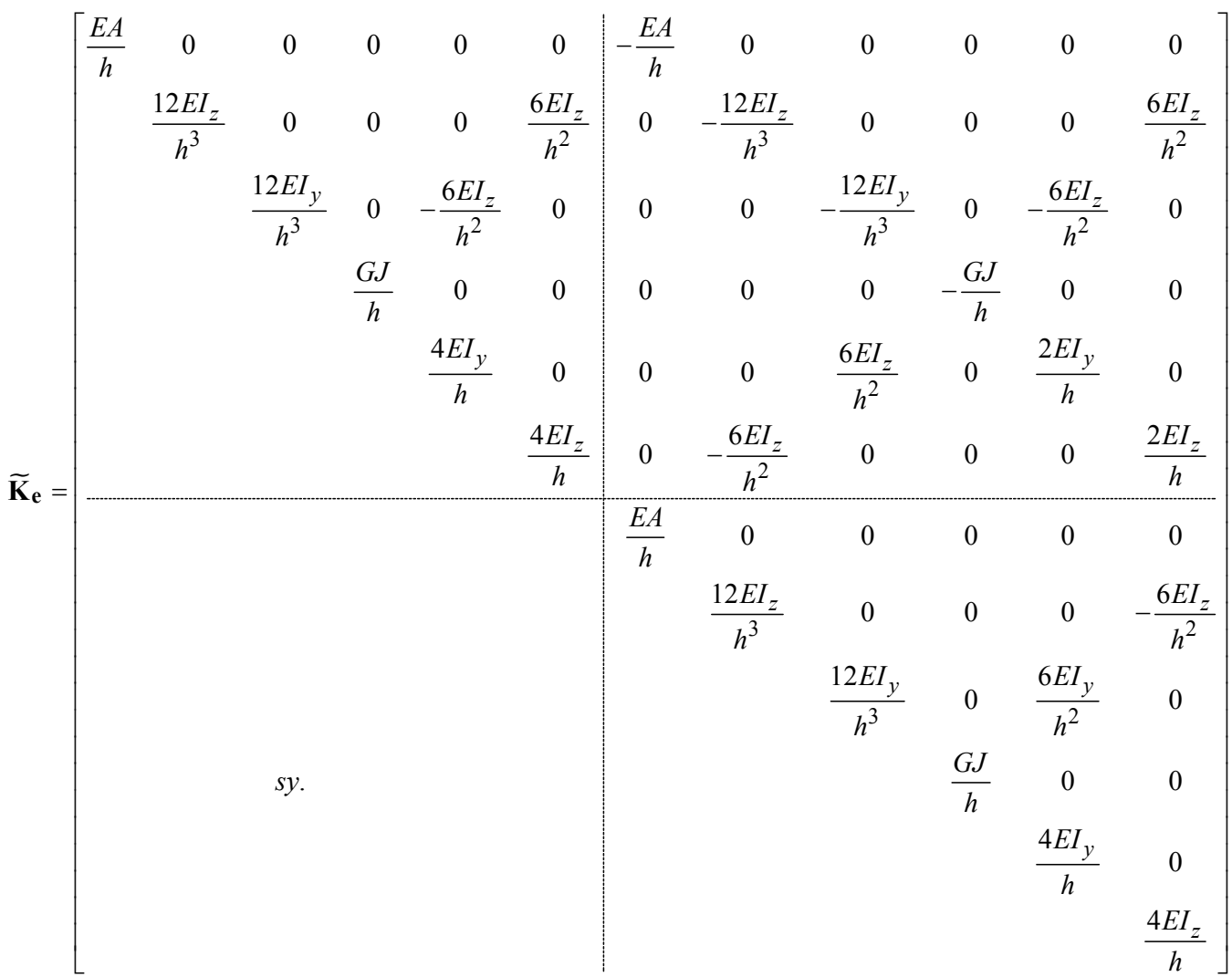

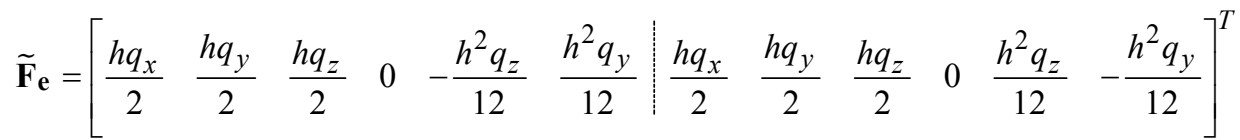


In order to assemble the beam elements, they have to be transformed from the $X Y Z$ local coordinate system to the $x y z$ global coordinate system (Figure 6). This can be conducted by using a proper $3 \mathrm{D}$ rotation matrix [8].

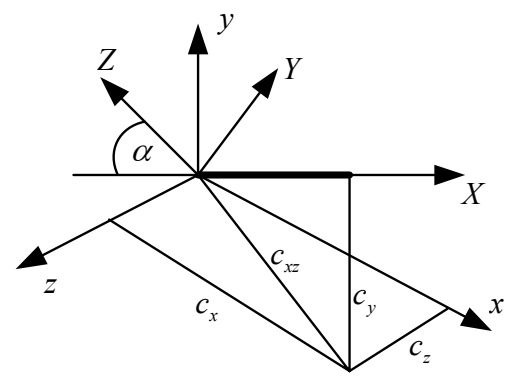

Figure 6. Transformation from local to global coordinate system

Utilizing the notations in Figure 5, the rotation matrices around different axes are:

$$
\begin{gathered}
\mathbf{T}_{\mathbf{x}}=\left[\begin{array}{ccc}
1 & 0 & 0 \\
0 & \cos \alpha & \sin \alpha \\
0 & -\sin \alpha & \cos \alpha
\end{array}\right], \\
\mathbf{T}_{\mathbf{y}}=\left[\begin{array}{ccc}
c_{x} / c_{x z} & 0 & c_{z} / c_{x z} \\
0 & 1 & 0 \\
-c_{z} / c_{x z} & 0 & c_{x} / c_{x z}
\end{array}\right], \\
\mathbf{T}_{\mathbf{z}}=\left[\begin{array}{ccc}
c_{x z} & c_{y} & 0 \\
-c_{y} & c_{x z} & 0 \\
0 & 0 & 1
\end{array}\right] .
\end{gathered}
$$

The 3D $\mathbf{T}_{\mathbf{x y z}}$ rotation matrix is the product of the above three matrices. The system matrices can be transformed with the following block-diagonal transformation matrix:

$$
\mathbf{T}=\left[\begin{array}{llll}
\mathbf{T}_{\mathbf{x y z}} & & & \\
& \mathbf{T}_{\mathbf{x y z}} & & \\
& & \mathbf{T}_{\mathbf{x y z}} & \\
& & & \mathbf{T}_{\mathbf{x y z}}
\end{array}\right] .
$$

Utilizing this transformation matrix, the transformed mass-, stiffness matrices and nodal load vector of a beam element are:

$$
\begin{aligned}
\mathbf{M}_{\mathbf{e}} & =\mathbf{T}^{\mathbf{T}} \widetilde{\mathbf{M}}_{\mathbf{e}} \mathbf{T}, \\
\mathbf{K}_{\mathrm{e}} & =\mathbf{T}^{\mathbf{T}} \widetilde{\mathbf{K}}_{\mathbf{e}} \mathbf{T}, \\
\mathbf{F}_{\mathbf{e}} & =\mathbf{T}^{\mathbf{T}} \widetilde{\mathbf{F}}_{\mathbf{e}} .
\end{aligned}
$$

\subsection{Wind load of the ladder}

The main - and the most dangerous - load that acts on the ladder is the pressure of the wind. As this is directly not known, only the velocity of the wind can be determined, the wind velocity has to be converted into wind pressure [9]. There are several ways to determine the wind pressure, in this paper it was calculated according to [10]. According to this, the basic wind velocity is defined as:

$$
v_{b}=c_{\text {dir }} c_{\text {season }} v_{b, 0},
$$

where $v_{b, 0}$ is the fundamental value of the basic wind velocity. The directional factor $c_{d i r}$ and the seasonal factor $c_{\text {season }}$ take into account the effects of wind direction and time of the year. Their values are generally equal to 1 .

The terrain roughness depends on the chosen terrain category. In this paper a terrain category III was chosen for the calculations, which means an area with regular cover of vegetation or buildings or with isolated obstacles with separations of maximum 20 obstacle heights (such as villages, suburban terrain, permanent forest). The corresponding parameters of this terrain category are roughness length $z_{0}=0.3 \mathrm{~m}$ and minimum height $z_{\min }=5 \mathrm{~m}$. Based on these parameters, the terrain factor can be calculated as follows:

$$
k_{r}=0.19\left(z_{0} / 0.05\right)^{0.07} .
$$

The roughness factor $c_{r}(z)$ at the reference height accounts for the variability of the mean wind velocity at the site of the structure due to the height above ground level and the ground roughness of the terrain upwind of the structure. It is calculated with the following formula:

$$
\begin{aligned}
& c_{r}(z)=k_{r} \cdot \ln \left(\frac{z}{z_{0}}\right) \text { for } \quad z_{\min } \leq z \\
& c_{r}(z)=c_{r}\left(z_{\min }\right) \quad \text { for } \quad \mathrm{z}<\mathrm{z}_{\min }
\end{aligned}
$$

The mean wind velocity $v_{m}(z)$ depends on the terrain roughness, the basic wind velocity and the orography factor $c_{0}(z)$, which takes into account the effect of hills and cliffs. For the calculations it was neglected, thus $c_{0}(z)=1$ was considered:

$$
v_{m}(z)=c_{r}(z) c_{0}(z) v_{b} .
$$

The wind turbulence is defined as the standard deviation of the turbulence divided by the mean wind velocity:

$$
\begin{array}{ll}
l_{v}(z)=\frac{k_{l}}{c_{0}(z) \ln \left(\frac{z}{z_{0}}\right)} & \text { for } \quad \mathrm{z}_{\min } \leq z \\
l_{v}(z)=l_{v}\left(z_{\text {min }}\right) & \text { for } \quad \mathrm{z}<\mathrm{z}_{\text {min }}
\end{array}
$$

The velocity pressure at height $z$ should be determined as:

$$
p(z)=\left[1+7 l_{v}(z)\right] \cdot 0.5 \cdot \rho \cdot v_{m}^{2}(z) .
$$

The calculation of the nodal force vector requires the velocity line load acting on a beam element, therefore the calculated velocity pressure on each element was multiplied by the dimension of the element perpendicular of the wind speed. The reference height, $z$ was considered at the midpoint of each beam element. In order to simplification, a constant velocity line load was applied to all beams subjected to wind velocity. As from equation (17) can be seen, the load changes with height according to a second order function. 
Two load cases were investigated, in the first case the wind load is applied in $y$ direction, while in the second case in $x$ direction.

\section{RESULTS}

To analyze the deflection of the ladder caused by wind load, four different wind events have been applied using linear representation of their associated ramps:

a) Wind rise: a $20 \mathrm{~km} / \mathrm{h}$ wind speed increases to 60 $\mathrm{km} / \mathrm{h}$ within 1 second

b) Wind gust: a $20 \mathrm{~km} / \mathrm{h}$ wind speed increases to 80 $\mathrm{km} / \mathrm{h}$ then falls down to $20 \mathrm{~km} / \mathrm{h}$ within 1 second

c) Wind lull: a $60 \mathrm{~km} / \mathrm{h}$ wind speed dies out and then rises up again to $60 \mathrm{~km} / \mathrm{h}$

d) Wind die-out: a $60 \mathrm{~km} / \mathrm{h}$ wind speed decreases to $20 \mathrm{~km} / \mathrm{h}$ within 1 second.

The effects of wind gusts with velocities higher than the operational wind velocities were investigated because - according to firefighters - the location of buildings, especially in larger cities with ten-storey housing estates may result in direct and reflective wind gusts that exceed the allowable wind force. In addition, sudden changes in wind direction complicate highaltitude rescue tasks.

The aim of the research is to identify the phenomena that occur in sudden wind gusts which lead to damage of the ladder structure and to facilitate the safe execution of firefighters' high-altitude rescue tasks by examining the swings of ladder structure, thus also providing a more effective preparation of the intervening firefighters for the effects of possible wind gusts.

Figure 7 and Figure 8 show the response of the top of the ladder induced by the above four wind event cases. To get the response of the ladder, the (1) equation of motion of the ladder was solved in time domain with Newmark method [6].

According to Figure 7, the wind event notated with a) yields to approximately $400 \mathrm{~mm}$ swaying in $y$ direction and $150 \mathrm{~mm}$ in $x$ direction, while the displacement in the vertical $z$ direction is approximately $50 \mathrm{~mm}$. The shapes of all the three displacement curves are harmonic with good approximation.
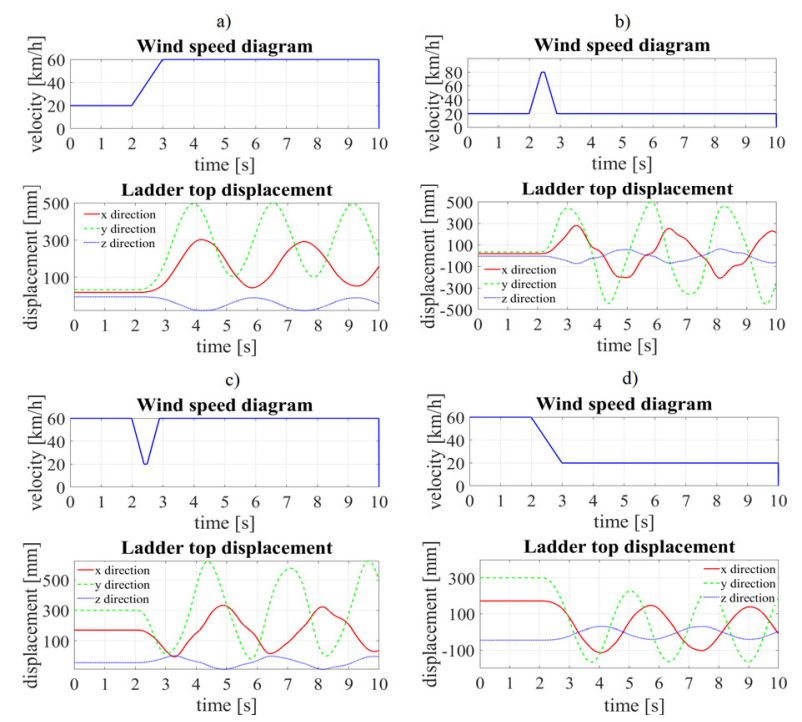

Figure 7. Displacements of the top of the ladder due to different wind events in y direction
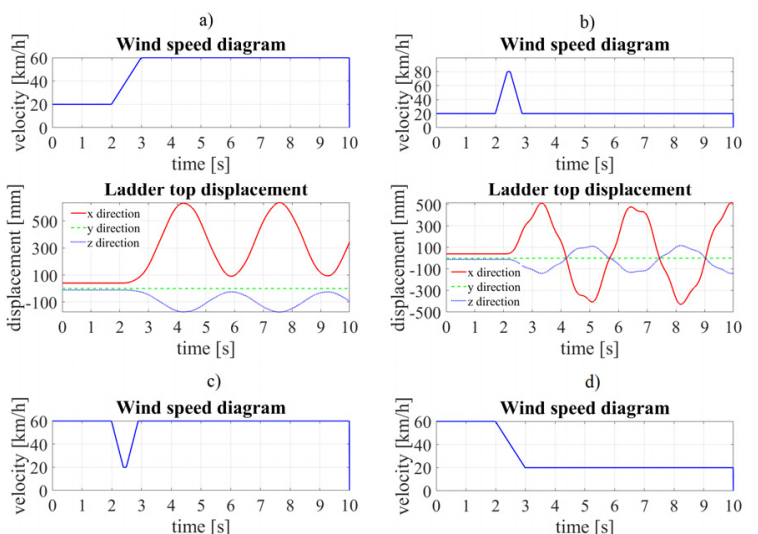

d)
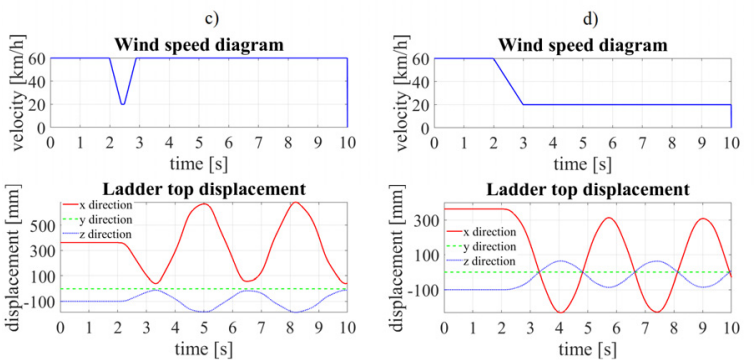

Figure 8. Displacements of the top of the ladder due to different wind events in $x$ direction

In case of the b) wind gust, the displacements in all 3 directions are considerably higher, more than twice as big as in case a), in $y$ and $x$ directions it almost reaches 1 meter and half meter, respectively. The shape in this case is more complex, since more mode shapes are involved in this type of excitation.

The c) wind lull load case provides similar results, with slightly lower amplitudes, while the d) wind dieout case is similar to the a) wind rise case considering either the amplitudes or the shape of the curve.

It can be seen from Figure 8, that compared to the excitation in $y$ direction in this case swaying in $y$ direction doesn't appear. The swaying has approximately 600 $\mathrm{mm}$ amplitude in case of wind rise, $1 \mathrm{~m}$ amplitude in case of wind gust, $600 \mathrm{~mm}$ amplitude in case of wind lull and $0.5 \mathrm{~m}$ amplitude in case of wind die-out.

According to the above 2 Figures, the most dangerous load case is the b) wind gust with a swaying of $1 \mathrm{~m}$ amplitude regardless the direction of the excitation.

\section{CONCLUSIONS}

In this research the wind loads and their effects on the Magirus M32L aerial ladder were investigated at full working height. A novel 3D beam model of the aerial ladder was developed. With finite element simulations it was concluded that the most dangerous load on the ladder structure is the sudden wind gust. It was determined that the pressure created by sudden wind gusts can swing the ladder structure up to $1 \mathrm{~m}$, which has a serious operational risk, especially at maximum load. For example, the ladder may strike a building structure, which may cause structural damage or the people in the rescue basket may be injured. In order to understand the effects of wind load on the ladder structure, it important to carry out further simulations that can be used in practice in the future.

\section{ACKNOWLEDGMENT}

The Authors would like to thank to EFOP-3.6.1-162016-00017 'Internationalization, initiatives to establish a new source of researchers and graduates, and 
development of knowledge and technological transfer as instruments of intelligent specializations at Széchenyi István University' for the support of the research

\section{REFERENCES}

[1] Biczó I.: Special fire-fighting vehicles, trailers, agents and equipment (in Hungarian), BM Könyvkiadó, Budapest, Hungary, 1977

[2] Scheugl L., Kurtz J., Rixen D.: Security by employing high altitude rescuers (in German), A. C. Ehlers Medienproduction Kiel, 2015

[3] Bernocco S,. Andrus J.: Safe and Effective Aerial Ladder Operations, Fire Engineering, Vol. 156, No. 10, pp. 91-95., 2003

[4] Tian, Z.-J. et al.: Design and analysis of uptilted aerial ladder for fire truck format. MATEC Web of Conferences. Vol. 207. EDP Sciences, 2018

[5] Horváth P.: Basics of Mechatronics II (in Hungarian), Széchenyi István University, Győr, Hungary, 2006

[6] Bathe K.-J.: Finite element procedures, KlausJurgen Bathe, Watertown, Massachusetts USA, 2016

[7] Hartmann F., Katz C.: Structural Analysis with Finite Elements, Springer-Verlag Berlin Heidelberg, Germany, 2007

[8] Segerlind L. J.: Applied Finite Element Analysis, Wiley, John, and Sons, Incorporated, New York, N.Y., USA, 1976

[9] Solazzi L., Zrnić N.: Numerical study of wind actions applied to a low profile container crane, FME Transactions Vol. 44. No.1 p. 29-35., 2016

[10] EN 1991-1-4:2005: Eurocode 1: Actions on structures - Part 1-4: General actions - Wind actions The
European Union Per Regulation 305/2011, Directive 98/34/EC, Directive 2004/18/EC

\section{ИСТРАЖИВАЊЕ ЊИХАҢА ИЗАЗВАНОГ \\ ИЗНЕНАДНИМ ОПТЕРЕТЕЊЕМ ВЕТРОМ ПРИ КОРИШЋЕЊУ ВАЗДУШНИХ МЕРДЕВИНА}

\author{
П. Хорват, Ф. Хајду, Р. Кути
}

У Мађарској, као и у другим земљама широм света, интервентне ватрогасне јединице често користе механичке ваздушне мердевине у извршавању задатака спасавања на великим висинама. Безбедно функционисање опреме је могуће само у условима строгих прописа и захтева велику стручност ватрогасног тима. Током сваке интервенције може да дође до изненадних налета ветра што изазива екстремно оптерећење елемената структуре мердевина и има негативног утицаја на опрему, а што може да доведе до кварова или, још горе, несрећних случајева. Зато је важно проучити последице деловања спољашњих фактора на ваздушне мердевине током њиховог коришћења. Испитивање је обављено на мердевинама типа Magirus M32-L jep се оне највише користе. Наш избор су биле ове мердевине sбог великог броја функција, тако да су резултати испитивања били добра полазна тачка за тестирање друге сличне опреме. У раду је приказан модел греде и симулације извршене помоћу ФЕМ методе. Циљ истраживања је био да се развије модел базиран на подацима геометријских мерења који је погодан за проучавање утицаја налета ветра на структуру мердевина. Желели смо да дамо допринос безбедном функционисању ваздушних мердевина и да спречимо могуће незгоде. 